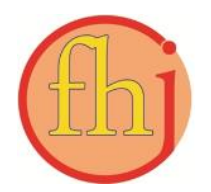

Faletehan Health Journal, 8 (3) (2021) 216-222

www. journal.Ippm-stikesfa.ac.id/ojs/index.php/FHJ

ISSN 2088-673X | e-ISSN 2597-8667

\title{
Pengalaman Aktivitas Spiritual pada Orang dengan HIV/AIDS (ODHA) dalam Menjalani Proses Penyakitnya
}

\author{
Chiyar Edison ${ }^{1 *}$, Setyowati ${ }^{1}$, Agung Waluyo $^{1}$ \\ ${ }^{1}$ Fakultas IImu Keperawatan, Universitas Indonesia \\ *Correspondence Author: chiyar.edison@gmail.com
}

\begin{abstract}
Abstrak
Kesejahteraan spiritual merupakan domain yang mempengaruhi luaran dari terapi antiretroviral pada ODHA. Namun, saat ini kebutuhan spiritual pada ODHA masih belum optimal terpenuhi dalam tatanan layanan kesehatan. Oleh karena itu, penting diketahui pengalaman spiritual pada ODHA untuk diketahui gambaran kebutuhannya. Penelitian fenomenologi deskriptif ini bertujuan untuk mengeksplorasi pengalaman spiritual ODHA selama menjalani proses penyakitnya dengan melibatkan lima partisipan dalam wawancara mendalam. Analisis konten tematik menghasilkan lima tema besar, yaitu: (1) Mendapatkan hidayah, dekat dengan agama, lebih takut dengan dosa dan lebih rajin sholat dan membaca kitab suci; (2) Pasrah dan menerima penyakitnya karena ini adalah teguran, cobaan dan kekuasaan Allah; (3) Dukungan ibu yaitu mengajak ke pengajian dan diingatkan untuk dzikir; (4) Mengalami kesedihan, syok, menyalahkan orang lain sehingga ingin mengakhiri hidup dan menghindari orang lain; (5) Harapan partisipan adalah sehat di dunia, dan beruntung di akhirat. Studi ini merekomendasikan penelitian lebih lanjut secara kuantitatif serta perlunya pengkajian spiritualitas pada ODHA dalam praktik asuhan keperawatan.
\end{abstract}

Kata Kunci: ODHA, aktivitas spiritual

\section{Spiritual Activities Experience of People Living with HIV/AIDS (PLWH) in the Disease Process}

\begin{abstract}
Spiritual well-being is a domain affecting the outcome of antiretroviral therapy in PLWH. However, spiritual need recently is still not adequately fulfilled in health service system. Therefore, it is essential to recognize the spiritual experience in PLWH to identify the depiction of their needs. This descriptive phenomenological study aimed to explore the spiritual experience of PLWH in the disease process by involving five participants in in-depth interviews. The thematic content analysis resulted five themes, namely (1) Obtaining guidance, being more religious, being more afraid of sin, more diligent in praying and reading the holy book; (2) Surrender and accept the illness because this is a warning, test and power of Allah; (3) Support from mother by encouraging to recitation and reminding to dhikr; (4) Experiencing sadness, shock, blaming others so that they want to end their life and avoid other people; (5) The participants hope to be healthy in this world and lucky in the hereafter. This study recommended further studies quantitatively and the assessment of PLWH spirituality in the nursing care practice.
\end{abstract}

Keywords: PLWH, Spiritual Activity 
Faletehan Health Journal, 8 (3) (2021) 216-222

www. journal.Ippm-stikesfa.ac.id/ojs/index.php/FHJ

\section{Pendahuluan}

Saat ini populasi Orang Hidup Dengan HIV/AIDS (ODHA) di dunia terus mengalami peningkatan. UNAIDS pada tahun 2019 melaporkan bahwa jumlah ODHA di dunia pada tahun 2018 mencapai 37,9 juta, di mana sebelumnya pada tahun 2010 berada di angka 31,7 juta. Sedangkan di Asia dan Pasifik, angka ODHA mencapai 5,9 juta (UNAIDS, 2019). Di Indonesia, angka ODHA juga terus mengalami peningkatan tiap tahunnya. Pada tahun 2017, tercatat jumlah kasus HIV mencapai 43.800, dimana angka menunjukan adanya peningkatan lebih dua kali lipat di banding tahun 2012 yang masih berada di posisi 21.511. Adapun propinsi Jawa timur, DKI Jakarta dan Jawa Barat menempati sebagai tiga propinsi tertinggi dalam angka HIV di Indonesia (InfoDATIN, 2018).

ODHA bisa mengalami penurunan kualitas hidup, bahkan status kualitas hidup ODHA lebih buruk dibanding populasi umum dan penyakit kronik lainnya (Miners et al., 2016). Pengukuran kualitas yang hidup pada 216 ODHA di Indonesia menunjukan masalah kelelahan dan gangguan tidur menjadi prioritas (Lindayani et al., 2018). Pada 88 ODHA di salah satu rumah sakit Jakarta, hubungan sosial menjadi domain yang paling rendah diantara domain kualitas hidup lain (Handajani et al., 2012). Secara singkat, kualitas hidup pada ODHA masih menjadi target pencapain penting yang perlu diperhatikan.

Kualitas hidup pada ODHA dipengaruhi oleh faktor-faktor seperti kepatuhan Antiretroviral (ARV), tingkat religius, penerimaan keluarga dan stadium klinis (Desyani et al., 2019; Dutra et al., 2019; Surur et al., 2017). Adanya kepatuhan ARV yang adekuat, maka luaran terapi pada ODHA seperti viral load, dan nilai CD4 akan tercapai secara optimal sehingga ODGA mampu menjalankan aktivitas kehidupan dengan baik (Briongos Figuero et al., 2011; Geocze et al., 2010; Liping et al., 2015). Kepatuhan ARV merupakan salah satu faktor yang sering ditemukan mempengaruhi kualitas hidup pada ODHA (Liping et al., 2015). Hal ini menunjukan kepatuhan ARV menjadi target luaran yang sangat penting pada penanganan ODHA. Namun, tingkat kepatuhan ARV di Indonesia masih perlu di tingkatkan. Sebuah penelitian yang dilakukan pada 276 ODHA di Jakarta, dilaporkan ada 23\% tidak patuh pada ARV (Weaver et al., 2014). Penelitian lainnya pada 201 ODHA di RSUP Hasan Sadikin Jawa Barat, ditemukan adanya $41,8 \%$ yang tidak patuh ARV (Puspasari et al., 2018). Ketidakpatuhan ARV juga terlaporkan 52\% di kota Medan pada 175 Lelaki Suka Lelaki (LSL) (Martiana et al., 2019). Hal ini menunjukan angka ketidakpatuhan ARV di Indonesia masih perlu menjadi catatan penting dalam perawatan ODHA.

Banyak studi yang dilakukan untuk mengidentifikasi faktor-faktor yang berkontribusi dalam kepatuhan ARV, salah satunya adalah aspek spiritual. Spiritual menjadi satu aspek yang telah terbukti adanya hubungan positif terhadap kepatuhan ARV (Ayuk, 2017; Kisenyi et al., 2013). Ada juga studi yang menunjukan bahwa semakin tinggi tingkat spiritual ODHA, akan semakin besar ketergantungannya terhadap Tuhan dan pada akhirnya tidak patuh pada ARV (Szaflarski, 2013). Oleh karena itu, spiritual menjadi domain penting yang perlu dilakukan investigasi lebih jauh. Namun sayangnya, penelitian terkait hal tersebut belum banyak di Indonesia khususnya pada target luaran terapi ODHA.

Di dalam konsep holistik, spiritual juga menjadi salah satu aspek yang mempunyai peranan penting dalam mempengaruhi invidu dalam mendefinisikan hidup sehat sakitnya (Szaflarski, 2013; Tuck, 2012). Namun, spiritual menjadi salah satu aspek yang sering kali diabaikan keberadaannya di dalam praktik karena perawat menjadi bingung dalam menerapkan konsep spiritual yang dipahami ke dalam bentuk praktik asuhan keperawatan yang diberikan (Moraes, 2015). Hal ini menunjukan bahwa semakin pentingnya komponen spiritualitas pada ODHA.

Spiritual secara ilmiah terbukti mempunyai peranan penting dalam mempengaruhi kepatuhan ARV pada ODHA. Namun, praktik pemenuhan kebutuhan spiritual di asuhan keperawatan masih belum optimal sebagai bentuk pelayanan keperawatan yang holistik. Oleh karena itu, perlu adanya peningkatan kualitas asuhan dalam memenuhi kebutuhan spiritual pada ODHA. Sebagai data dasar untuk mengidentifikasi kebutuhan spiritual, maka perlu dilakukan penggalian secara mendalam terkait pengalaman spiritual pada ODHA. Oleh karena itu, penelitian ini bertujuan untuk melihat pengalaman aktivitas spiritual pada ODHA dalam menjalani proses penyakitnya. 


\section{Metodologi Penelitian}

Penelitian ini menggunakan pendekatan berupa kualitatif dengan desain fenomenologi deskriptif dengan in depth interview. Populasi target penelitian ini adalah ODHA di Indonesia, sedangkan populasi terjangkaunya merupakan ODHA yang berada di kawasan Depok. Teknik sampling yang digunakan adalah purposive sampling. Total terdapat lima partisipan yang bergabung dalam penelitian ini. Adapun kriteri inklusi pasien ini adalah: (Burhan et al.) Pasien terdiagnosa positif HIV; (2)Pasien mempunyai usia diatas 18 tahun. Hal ini bertujuan agar pengalaman yang didapatkan berdasarkan usia dewasa, dimana pengalaman spiritual sudah mampu didefinisikan dengan baik; (3).Pasien mampu berkomunikasi dengan baik.

Peneliti bekerja sama dangan aktivis HIV/AIDS yang berasal dari LSM Kuldesak dan KPA Walikota Depok membuka rekrutmen penelitian ini. Setelah mendapatkan ada partisipan, peneliti menjelaskan terlebih dahulu informsi penelitian dan menanyakan persetujuannya. Jika partisipan setuju, peneliti akan membuat perjanjian untuk bertemu untuk dilakukan wawancara. Penelitian dilakukan di rumah LSM Kuldesak dan KPA di kantor walikota Depok. Setelah memeroleh ijin penelitian, maka tim peneliti melakukan wawancara di salah satu ruangan tertutup di rumah LSM, dengan pintu yang tertutup demi menjaga privasi partisipan. Partisipan juga diinformasikan bahwa jika mereka merasa tidak nyaman selama wawancara, maka wawancara dapat dihentikan sementara sampai partisipan merasa nyaman kembali. Selama wawancara, partisipan juga diberitahukan dapat mengundurkan diri bila diinginkan. Tidak ada unsur paksaan bagi partisipan untuk berpartisipasi pada penelitian ini. Semua arsip data yang sudah terkumpul akan disimpan pada loker yang terkunci. Untuk mengakses loker ini, kunci hanya dimiliki oleh tim peneliti. Semua informasi dan data terkait subjek penelitian akan disimpan dengan baik dan dijaga kerahasiannnya. Semua transkrip hanya mencamtumkan inisial partisipan.

Pengumpulan data dilakukan dengan cara wawancara mendalam (in depth interview). Wawancara dilakukan di kantor LSM Kuldesak dan kantor walikota depok, khususya di salah satu ruangan tertutup demi menjaga privasi partisipan. Lama wawancara yang dilakukan bervariasi antara satu partisipan dengan partisipan lainnya, dengan rentang waktu antara 35-50 menit. Selama wawancara, peneliti merekam proses wawancara menggunakan digital voice recorder. Semua transkrip dibaca berkali-kali oleh peneliti setiap selesai dilakukannya wawancara.

Teknik analisis data yang digunakan adalah analisis konten tematik dimana peneliti melakukan koding pada setiap jawaban dari pertanyaan yang sesuai tujuan penelitian. Koding-koding ini terlihat dari highlight warna pada transkrip wawancara dan setiap bagian kalimat yang diwarnai diberikan klasifikasi kategori. Kategori-kategori lalu diidentifikasi kesamaannya dari masing-masing partisipan, yang mana dari kategori-kategori akan dijadikan satu tema yang terbentuk.

\section{Hasil dan Pembahasan Karakterisktik partisipan}

Pada penelitian melibatkan total lima partisipan yang semuanya beragama Islam. Terdapat usia yang berentang dari umur 27 sampai 42 tahun. Partisipan terdiri dari dua pria dan tiga perempuan. Dari latar belakang pendidikan, partisipan mempunyai riwayat pendidikan S1, SMA dan SMP. Sedangkan jenis pekerjaan hampir semua sudah tidak bekerja, hanya dua partisipan yang masih bekeja. Partisipan juga berasal dari bermacam-macam suku asal, yaitu Jawa, Sumatera dan betawi. Semua partisipan perempuan mempunyai status janda, sedangkan dua partisipan pria lainnya sudah menikah dan belum menikah.

\section{Analisis Konten Tematik}

Tema 1: Mendapatkan hidayah, dekat dengan agama, lebih takut dengan dosa dan lebih rajin dalam sholat dan baca kitab suci

Seluruh partisipan menunjukan adanya perubahan dalam hubunganya dengan Tuhan. Tema ini didukung oleh kategori sebagai berikut:

1. Mendapatkan hidayah, lebih dekat dengan agama, lebih takut dosa

Kategori ini muncul karena terdapat empat partisipan yang menyatakan mengalami peningkatan hubungan dengan Tuhan. Berikut contoh dua kutipan dari empat partisipan tersebut:

"disaat kita belum kena HIV, mungkin diri saya gak sebaik ini, tapi pas kena HIV, gak tahu kita harus jemput hidayah, hidup pas sebelum kena HIV kan brutal, semau-mau gue.." (P1) 
Faletehan Health Journal, 8 (3) (2021) 216-222

www. journal.Ippm-stikesfa.ac.id/ojs/index.php/FHJ

ISSN 2088-673X | 2597-8667

Tabel 1. Karakteristik Partisipan

\begin{tabular}{cccccccc}
\hline $\mathbf{P}$ & Usia & $\begin{array}{c}\text { Jenis } \\
\text { kelamin }\end{array}$ & $\begin{array}{c}\text { Latar Belakang } \\
\text { Pendidikan }\end{array}$ & Pekerjaan & Suku Asal & $\begin{array}{c}\text { Status } \\
\text { Menikah }\end{array}$ & Agama \\
\hline 1 & 42 & Pria & SMP & Tak bekerja & Betawi & $\begin{array}{c}\text { Belum } \\
\text { Menikah }\end{array}$ & Islam \\
\hline 2 & 34 & Perempuan & SMP & Tak bekerja & Betawi & Janda & Islam \\
\hline 3 & 27 & Perempuan & SMA & $\begin{array}{c}\text { Ibu rumah } \\
\text { tangga/aktivis }\end{array}$ & Jawa & Janda & Islam \\
\hline 4 & 33 & Perempuan & SMA & $\begin{array}{c}\text { Sekretaris } \\
\text { LSM }\end{array}$ & Jawa & Janda & Islam \\
\hline 5 & 35 & Pria & S1 & Tak bekerja & Sumatera & Menikah & Islam \\
\hline
\end{tabular}

"kalo sekarang lebih ke arah iman kali yah, jadi lebih ngejaga, jadi kalo menurut agama agak boleh gak akan kau ngelakuin. Kalo menurut agama salah gak akan aku lakuin, kalo menurut agama haram gak akan dilakuin.." (P3)

2. Sholat lebih rajin dan tepat waktu, lebih rajin baca kitab suci, banyak doa dan mengikuti pengajian

Semua partisipan menyatakan adanya peningkatan kualitas dalam beribadah. Berikut contoh kutipan dari dua partisipan:

"sekarang udah berubah, sedikit sedikit aku bisa ngerjain, ngerjain sholat gitu kan, walaupun gak $100 \%$ gitu kan, sedikit sedikit bisa baca quran..” (P2)

"Kalo sekarang itu lebih sering sholat malam , mungkin karena dibangunin sama Allah.." (P4)

Tema 2: Pasrah dan menerima penyakitnya karena ini adalah teguran, cobaan dan kekuasaan Allah

Seluruh partisipan mempunyai koping tersendiri dalam menerima dan menjalani penyakitnya yang dihubungkan dengan Tuhannya. Adapun kategori yang membentuk tema ini adalah sebagai berikut:

1. Penyakit ini diterima, pasrah dan dijalankan saja Ada

Terdapat empat partisipan yang memberikan pandangan bahwa penyakit ini harus diterima, pasrah dan dijalankan saja. Berikut salah satu contoh kutipan dari empat partisipan:

"Dan yang saya sekarang hadapin yah jalanin, terima, karena mau marah-marah mau gimana lagi,..." (P2)
2. Penyakit ini merupakan cobaan, teguran dan kekuasaan Allah

Ada tiga partisipan yang mendasari kategori ini. Berikut salah satu contoh kutipan dari tiga partisipan tersebut:

"mungkin ini teguran dari Allah, ini udah cukup lo dikasih ini, lo dapat ini gw kasih ini supaya bisa berubah, bisa tobat supaya lo gak balik ke tabiat yang lama" (P3)

Tema 3: Dukungan ibu yaitu mengajak ke pengajian dan diingatkan untuk dzikir

Ada tiga partisipan yang menyatakan ibu mereka mendukung dalam aktivitas ibadah seperti pergi ke pengajian dan dzikir. Tema ini didukung oleh dua kategori yaitu:

1. Pergi ke pengajian diajak ibu

Kategori ini dibentuk oleh dua partisipan.

Berikut salah satu contohnya:

"dulu kan aku gak pernah ngaji, kalo sekarang ada jadwal terntu, sekali seminggu pengajian bareng rutin, kalo dulu mah gak pernah..Ini ide mama.."(P2)

2. Ibu mengingatkan dzikir

Ada satu partisipan yang memberikan pernyataan terkait kategori ini, berikut kutipannya:

"kalo gak enak badan, karena mama ingetin kalo lagi gak enak badan ddzikiran,.."(P3)

Tema 4: Mengalami kesedihan, syok, menyalahkan orang lain sehingga ingin mengakhiri hidup dan menghindari orang lain

Semua partisipan menunjukan adanya perasaan yang sedih, syok menyalahkan orang lain bahkan ada percobaan ingin mengakhiri hidup serta menghindari orang lain. Tema ini terbentuk dari tiga kategori, yaitu: 
1. Perasaan sedih, bingung, syok dan down Kategori ini didukung dari hasil wawancara pada empat partisipan. Berikut merupakan dua contoh kutipannya:

“....awal-awal saya kena itu, kalo kata orang penyakit ini gak ada obatnya. Itu saya sempat rasain down...(P1)

"Sedih, bigung, gak percaya kenapa harus terjadi sama saya, saya ini perempuan baik baik, gak pernah pake narkobva, seks veresiko, rasa gak terima itu ada (P3)

2. Menyalahkan orang lain dan kehidupan

Ada dua partisipan yang memberikan pernyataan sesuai dengan kategori ini. Berikut salah satu contohnya:

“..sebulan lah aku nyalahin orang. Nyalahin suami almarhum ku itu...gara-gara lo itu gw kena, cuman kesininya aku mulau nerima keadaan. Pokonya dari setiap kejadian aku ambil hikmah" (P2)

3. Coba mengakhiri hidup, menghindari orang lain dan minta cerai.

Kategori ini berdasarkan pernyataan dari seorang partisipan. Berikut kutipannya:

“...trus ibu nya pas datang aku minta cerai. Saya gak mau dia lagi karena dia sudah gak bertanggung jawab dengan saya....” (P3)

\section{Tema 5: Harapan partisipan adalah sehat di dunia, dan beruntung di akhirat}

Terdapat empat partisipan yang mengutarakan harapan-harapannya untuk dunia dan akhirat. Tema ini didukung oleh tiga kategori sebagai berikut:

1. Keinginan untuk sehat

Ada dua partisipan yang mengatakan harapannya untuk sehat. Berikut salah satu kutipannya:

"Doanya yah kesehatan sih tentunya. Kesehatan buat aku, anak aku, buat mama aku. Kalo sehat kan enak yah mau ngapain aja. Kalo punya duit tapi gak sehat kan percuma.. "(P2)

2. Keinginan untuk beruntung dunia akhirat dan meninggalkan duniawi

Kategori ini disusun dari pernyataan dua partisipan. Berikut adalah kutipannya:

"saya minta ama Allah, yah Allah jadikan saya orang yang beruntung di dunia dan akhirat kelak, tuh doa saya selalu..” (P1)

"Ingin meninggalkan urusan dunia, namun belum bisa ..saya ingin menjadi mujahadah.." (P5)
Proses memaknai kehidupan dengan melibatkan hubungan dengan Tuhan dan sesama manusia, merupakan konsep utama dalam mencerminkan status spiritualitas (Carson \& Koenig, 2008). Begitu juga dengan ODHA, saat seorang individu mulai mendapatkan dirinya positif HIV, spiritualitas menjadi variabel inti yang paling mempengaruhi dalam merespon stresor baik dalam secara emosional, sosial dan biologis (Neuman \& Fawcett, 2011; Sulung \& Asyura, 2019).

Pada penelitian ini, hasil wawancara mendalam menunjukan bahwa penerimaan pada penyakit HIV/AIDS dipengaruhi oleh hubungan ODHA dengan Tuhan. Keikhlasan, ketabahan, dan penerimaan diri dikaitkan dengan bagaimana agama mempengaruhi kehidupan para partisipan. Hal ini sesuai dengan studi-studi sebelumnya yang menunjukan bahwa penerimaan diri akan penyakit HIV/AIDS melibatkan hubugan ODHA dengan Tuhan (Oji et al., 2017; Sulung \& Asyura, 2019). Spiritual sebagai variabel inti dalam sistem individu, mempunyai kekuatan besar dalam mempengaruhi individu berespon terhadap penyakitnya (Neuman, 2011). Ketika individu seperti ODHA menggantungkan dirinya pada Tuhan, maka hal ini akan membuat invidu lebih pasrah dan mudah dalam menerima kondisi penyakitnya (Szaflarski, 2013; Trevino et al., 2010). Walaupun demikian, beberapa ODHA juga menunjukan adanya distress spiritual dan kurang mampunya dalam memaknai kehidupan (Mourão Pinho et al., 2017). Sehingga bisa dikatakan, spiritualitas mempunyai peran dalam menentukan kemampuan ODHA dalam mendefinisikan tujuan kehidupan setelah didiagnosa positif HIV.

Adanya peningkatan aktivitas spiritual dalam beribadah seperti sholat, membaca Al-Quran, atau bahkan melakukan aktivitas yang tidak pernah dilakukan sebelum menderita HIV seperti pergi ke pengajian, menunjukan adanya perubahan dalam religiusitas ODHA semenjak positif HIV. Hal ini sejalan dengan studi-studi bahwa adanya hubungan yang positif antara kejadian HIV/AIDS pada tingkat religiusitas (Ntshakala et al., 2015; Szaflarski, 2013; Trevino et al., 2010). Peningkatan ibadah ini merupakan cara individu dalam menerima dirinya dengan penyakitnya (Unge et al., 2011). Sehingga hal ini membuat ODHA yakin bahwa dengan banyak beribadah, Tuhan akan lebih menjaganya dan menyembuhkannya. Namun, ketergantungan dengan doa-doa ini mampu 
Faletehan Health Journal, 8 (3) (2021) 216-222

www. journal.Ippm-stikesfa.ac.id/ojs/index.php/FHJ

ISSN 2088-673X | 2597-8667

memberikan dampak terhadap kepatuhan terapi, sepertinya ibadah puasa pada muslim. Beberapa studi menunjukan ketidakpatuhan ARV bisa terjadi karena meningkatnya ibadah puasa pada muslim (Unge et al., 2011; Wasti et al., 2012).

Keterlibatan keluarga juga tampak pada hasil penelitian ini, baik dalam membantu ODHA mendefinisikan tujuan hidup serta sebagai sistem pendukung dalam pengobatan dan aktivitas spiritual. Keluarga memang terbukti sebagai sistem pendukung yang efektif bagi kualitas hidup pada ODHA (Xu et al., 2017). Namun belum ada studi spesifik yang menjelaskan hubungan antara keluarga dengan status spiritualitas. Sehingga hal ini bisa menjadi rekomendasi pada penelitain selanjutnya.

\section{Simpulan}

Pengalaman ODHA dalam menjalankan aktivitas spiritual menunjukan sebuah perubahan dibanding sebelum terjangkit virus HIV. Perubahan aktivitas spiritual ini terlihat bagaiman ODHA memaknai tujuan kehidupannya dengan lebih mendekatkan diri pada Tuhannya, peningkatan intensitas dan jenis ibadah seperti sholat dan membaca kitab suci. Kegiatan ibadah ini pun melibatkan dukungan keluarga khususnya ibu dalam mengajak pergi ke pengajian ataupun berdzikir. Pada hubungan sosial, ODHA tampak lebih cenderung menutup diri tentang penyakitnya khususnya pada orang luar, namun tidak umtuk keluarga. Harapan-harapan yang muncul khususnya terkait keinginan untuk sehat serta beruntung di akhirat. Studi ini merekomendasikan perlunya penelitian lebih lanjut terkait bagaimana kualitas spiritual pada pasien ODHA secara kuantitatif. Selain itu perlunya pengkajian khusus yang dilakukan terkait spiritual pada pasien ODHA.

\section{Referensi}

Ayuk, A. E. (2017). Influence of Spirituality and Religion on Adherence to Highly Active Antiretroviral Therapy in Adult HIV/AIDS Patients in Calabar, Nigeria. Recent Adv Biol Med, 3(2017), 2006.

Briongos Figuero, L. S., Bachiller Luque, P., Palacios Martín, T., González Sagrado, M., \& Eiros Bouza, J. M. (2011). Assessment of factors influencing health-related quality of life in HIV-infected patients. HIV Medicine,
12(1), 22-30. https://doi.org/10.1111/j.14681293.2010.00844.x

[Record \#274 is using a reference type undefined in this output style.]

Carson, V. B., \& Koenig, H. G. (2008). Spiritual Dimension of Nursing Practice. Templeton Foundation Press.

Desyani, N. L. J., Waluyo, A., \& Yona, S. (2019, 2019/09/01/). The relationship between stigma, religiosity, and the quality of life of HIV-positive MSM in Medan, Indonesia. Enfermería Clínica, 29, 510-514. https://doi.org/https://doi.org/10.1016/j.enfcli .2019.04.077

Dutra, B. S., Lédo, A. P., Lins-Kusterer, L., Luz, E., Prieto, I. R., \& Brites, C. (2019). Changes health-related quality of life in HIV-infected patients following initiation of antiretroviral therapy: a longitudinal study. The Brazilian Journal Of Infectious Diseases: An Official Publication of The Brazilian Society of Infectious Diseases, 23(4), 211-217. https://doi.org/10.1016/j.bjid.2019.06.005

Geocze, L., Mucci, S., De Marco, M. A., NogueiraMartins, L. A., \& Citero, V. d. A. (2010). Quality of life and adherence to HAART in HIV-infected patients. Revista De Saude Publica, 44(4), 743-749. http://search.ebscohost.com/login.aspx?direct $=$ true $\& \mathrm{db}=$ mnh $\& \mathrm{AN}=20676564 \&$ site $=$ ehost live

Handajani, Y. S., Djoerban, Z., \& Irawan, H. (2012). Quality of life people living with HIV/AIDS: outpatient in Kramat 128 Hospital Jakarta. Acta Med Indones, 44(4), 310-316.

[Record \#95 is using a reference type undefined in this output style.]

Kisenyi, R. N., Muliira, J. K., \& Ayebare, E. (2013). Religiosity and adherence to antiretroviral therapy among patients attending a public hospital-based HIV/AIDS clinic in Uganda. Journal of Religion And Health, 52(1), 307-317. https://doi.org/10.1007/s10943-011-9473-9

Lindayani, L., Chen, Y.-C., Wang, J.-D., \& Ko, N.Y. (2018). Complex problems, care demands, and quality of life among people living with $\mathrm{HIV}$ in the antiretroviral era in Indonesia. Journal of the Association of Nurses in AIDS Care, 29(2), 300-309.

Liping, M., Peng, X., Haijiang, L., Lahong, J., \& Fan, L. (2015). Quality of Life of People 
Living with HIV/AIDS: A Cross-Sectional Study in Zhejiang Province, China. PloS one, 10(8), e0135705-e0135705. https://doi.org/10.1371/journal.pone.0135705

Martiana, I., Waluyo, A., \& Yona, S. (2019). Assessing the relationship between knowledge of antiretroviral therapy and stigma regarding adherence to ART among men who have sex with men. Enfermería Clínica.

[Record \#75 is using a reference type undefined in this output style.]

Moraes, O. (2015). Spiritual care in nursing practice: Nurses' perception. J Nurs UFPE, 9(8), 8817-8823.

Mourão Pinho, C., Tavares Gomes, E., Cordeiro Trajano, M. d. F., Tenório de Almeida e Cavalcanti, A., Sandra Andrade, M., \& Perrelli Valença, M. (2017). Impaired religiosity and spiritual distress in people living with HIV/AIDS. Revista Gaucha de Enfermagem, 38(2), 1-7. https://doi.org/10.1590/19831447.2017.02.67712

Neuman, B. (2011). The Neuman Systems Model (fifth ed.). Pearson.

Neuman, B. M., \& Fawcett, J. (2011). The Neuman systems model.

Ntshakala, T. T., Mavundla, T. R., \& Dolamo, B. L. (2015). Quality of life of people living with HIV and AIDS who are on antiretroviral therapy in Swaziland. Africa Journal of Nursing and Midwifery, 17(1), 17-32.

Oji, V. U., Hung, L. C., Abbasgholizadeh, R., Hamilton, F. T., Essien, E. J., \& Nwulia, E. (2017). Spiritual care may impact mental health and medication adherence in HIV+ populations. HIV/AIDS (Auckland, NZ), 9, 101.

Puspasari, D., Wisaksana, R., \& Rovina, R. (2018). Gambaran Efek Samping dan Kepatuhan Terapi Antiretroviral pada Pasien HIV di Rumah Sakit Dr. Hasan Sadikin Bandung tahun 2015. Jurnal Sistem Kesehatan, 3(4).

Sulung, N., \& Asyura, R. (2019). The analysis of spirituality of patients with HIV/AIDS in taking lessons and self-acceptance. Indian Journal Of Palliative Care, 25(2), 232-235. https://doi.org/10.4103/IJPC.IJPC_203_18

Surur, A. S., Teni, F. S., Wale, W., Ayalew, Y., \& Tesfaye, B. (2017). Health related quality of life of HIV/AIDS patients on highly active anti-retroviral therapy at a university referral hospital in Ethiopia. BMC Health Services Research, 17(1), 737-737. https://doi.org/10.1186/s12913-017-2714-1

Szaflarski, M. (2013). Spirituality and religion among HIV-infected individuals. Current HIV/AIDS Reports, 10(4), 324-332.

Trevino, K. M., Pargament, K. I., Cotton, S., Leonard, A. C., Hahn, J., Caprini-Faigin, C. A., \& Tsevat, J. (2010). Religious coping and physiological, psychological, social, and spiritual outcomes in patients with HIV/AIDS: cross-sectional and longitudinal findings. AIDS And Behavior, 14(2), 379-389. $\mathrm{http} / / /$ search.ebscohost.com/login.aspx?direct $=$ true $\& \mathrm{db}=\mathrm{mnh} \& \mathrm{AN}=18064557 \&$ site $=$ ehost live

Tuck, I. (2012). A critical review of a spirituality intervention. Western journal of nursing research, 34(6), 712-735.

UNAIDS. (2019). Global HIV \& AIDS statistics 2019 fact sheet. Retrieved 11 November 2019 from https://www.unaids.org/en/resources/factsheet

Unge, C., Ragnarsson, A., Ekström, A. M., Indalo, D., Belita, A., Carter, J., Ilako, F., \& Södergård, B. (2011). The influence of traditional medicine and religion on discontinuation of ART in an urban informal settlement in Nairobi, Kenya. AIDS care, 23(7), 851-858.

Wasti, S. P., Van Teijlingen, E., Simkhada, P., Randall, J., Baxter, S., \& Kirkpatrick, P. (2012). Factors influencing adherence to antiretroviral treatment in Asian developing countries: a systematic review. Tropical Medicine \& International Health, 17(1), 7181.

Weaver, E. R. N., Pane, M., Wandra, T., Windiyaningsih, C., Herlina, \& Samaan, G. (2014). Factors that influence adherence to antiretroviral treatment in an urban population, Jakarta, Indonesia. PloS one, 9(9), e107543-e107543.

https://doi.org/10.1371/journal.pone.0107543

Xu, J.-F., Ming, Z.-Q., Zhang, Y.-Q., Wang, P.-C., Jing, J., \& Cheng, F. (2017). Family support, discrimination, and quality of life among ART-treated HIV-infected patients: a twoyear study in China. Infectious diseases of poverty, 6(1), 152. 